\title{
Storage of nitrogen in the form of protein bodies in the kelp Laminaria solidungula
}

\author{
Curt M. Pueschel ${ }^{1, *}$, Rebecca E. Korb ${ }^{2}$ \\ ${ }^{1}$ Department of Biological Sciences, State University of New York at Binghamton, Binghamton, New York 13902-6000, USA \\ ${ }^{2}$ British Antarctic Survey, High Cross, Madingley Road, Cambridge CB3 0ET, United Kingdom
}

\begin{abstract}
Proteinaceous cytoplasmic inclusions with characteristic anatomical localization patterns are common in marine algae, but the function of these cell structures has not been demonstrated. Thalli of the endemic Arctic kelp Laminaria solidungula J. Agardh, cultured under N-replete conditions and examined by light and electron microscopy, were found to have a variety of cellular inclusions. One type of inclusion was shown by cytochemical methods to be proteinaceous. The protein bodies were 1 to $10 \mu \mathrm{m}$ in diameter, had a single bounding membrane, and occurred singly or in large clusters in cells of the cortex. Intact proteinaceous inclusions were absent from N-starved thalli, although structures presumed to be depleted protein bodies had an anatomical distribution comparable to that of the protein bodies in the N-replete algae. These findings on Laminaria solidungula provide the first experimental evidence in support of the hypothesis that proteinaceous cellular inclusions in marine macroalgae constitute a nitrogen store that, like the stores of nitrate and amino acids accumulated by many algae, could be utilized during seasons when nitrate concentrations in the water column are low but when photosynthetic carbon fixation must be maximized.
\end{abstract}

KEY WORDS: Nitrogen storage $\cdot$ Laminaria solidungula $\cdot$ Algae $\cdot$ Protein bodies $\cdot$ Arctic

\section{INTRODUCTION}

In marine waters nitrogen is the nutrient that most often limits macroalgal growth (e.g. Hanisak 1983). Seasonal $\mathrm{N}$ depletion is common on both temperate (Chapman \& Craigie 1977, Gagné et al. 1982) and Arctic shores (Chapman \& Lindley 1980). It is well known that algae experiencing nutrient limitation on a regular basis accumulate reserves of $\mathrm{N}$ that support growth when external supply is low. Nitrogen storage can occur in the form of inorganic ions accumulated without modification, i.e., $\mathrm{NO}_{3}^{-}$(e.g. Chapman \& Craigie 1977), or in a metabolized organic form such as amino acids (Bird et al. 1982, Naldi \& Wheeler 1999), or even as complex functional proteins such as enzymes or phycobiliprotein pigments (Bird et al. 1982, Levy \& Gantt 1990). Storing N as a functional product

*E-mail: curtp@binghamton.edu has the disadvantage that mobilization of the reservoir results in loss of metabolic function conferred by the stored material. Accumulation of soluble compounds has osmotic consequences for the cells and could limit their concentration. Potentially, the storage of proteins - either proteins without metabolic function or functional proteins produced in excess of metabolic need - could occur with little osmotic effect if they are deposited as insoluble inclusions.

Proteinaceous inclusions are widespread among red algae, usually occurring as cytoplasmic bodies with an angular outline and a periodic substructure, features that are indicative of a crystalline nature (Pueschel 1992). Crystalline inclusions were demonstrated in the cytoplasm of medullary cells of the brown alga Haplogloia kuckuckii (Chordariales) (Pueschel 1994), and a few reports describe crystals in kelps (Chadefaud 1936). Although it has been proposed (Pueschel 1990, $1992,1994)$ that microscopically demonstrable proteinaceous cellular inclusions in marine macroalgae might 
serve as a nitrogen reserve that can be mobilized during seasonal N-deficiency, this hypothesis has not been tested in any alga.

Laminaria solidungula J. Agardh is an endemic Arctic kelp that typically experiences summer $\mathrm{N}$ deficiency (Chapman \& Lindley 1980, Henley \& Dunton 1995). In culture studies, Korb \& Gerard (2000) demonstrated that this alga was able to sustain growth for at least 9 mo under $\mathrm{N}$ starvation by using inorganic, and later, organic $\mathrm{N}$ reserves. In the present study, light and electron microscopy revealed that protein bodies were abundant in blades of $\mathrm{N}$-replete thalli of L. solidungula but were absent under $\mathrm{N}$-deficient conditions, indicating that proteins in the form of distinctive cellular structures may provide a valuable $\mathrm{N}$ reserve in this alga during Arctic summer.

\section{MATERIALS AND METHODS}

Sporophytes of Laminaria solidungula were collected by SCUBA from the Canadian High Arctic at Resolute Bay, Cornwallis Island $\left(74^{\circ} 30^{\prime} \mathrm{N}, 95^{\circ} \mathrm{W}\right)$, during July 1997. Thalli, initially about $30 \mathrm{~cm}$ long, were cultured under either $\mathrm{N}$-replete or $\mathrm{N}$-limited conditions as part of the experiments of Korb \& Gerard (2000). Plants were maintained in 81 batch cultures with 5 or 6 thalli $\mathrm{tub}^{-1}$. Seawater from Long Island Sound was used at ambient salinity ( 28 to $30 \mathrm{psu}$ ), which was similar to the salinity at the collection site. Cultures were maintained in a temperature-controlled incubator at $0^{\circ} \mathrm{C}$. Irradiance was provided by cool-white fluorescent lamps at a photon flux density of 50 to $70 \mu \mathrm{mol} \mathrm{m}{ }^{-2} \mathrm{~s}^{-1}$, on a 16:8 h light:dark cycle. To maximize growth, plants were grown on a 20:4 h light:dark cycle for the last $6 \mathrm{wk}$ before sampling. Water motion was provided by aeration. Seawater, which was first stripped to $<1 \mu \mathrm{M}$ $\mathrm{NO}_{3}{ }^{-}$and $\mathrm{NH}_{4}{ }^{+}$by 3 to $4 \mathrm{~d}$ of exposure to Ulva lactuca cultures, was changed twice weekly. To produce $\mathrm{N}$ replete conditions, stripped seawater was enriched to $240 \mu \mathrm{M} \mathrm{NO}_{3}{ }^{-}$and $16 \mu \mathrm{M} \mathrm{PO}_{4}$ at each water change. These concentrations are known to saturate $\mathrm{N}$-content of blades in temperate L. saccharina (Gerard 1997). To produce N-limited plants, only $16 \mu \mathrm{M} \mathrm{PO}_{4}$ was added to the seawater.

After approximately 7 mo of experimental treatment (under either $\mathrm{N}$-replete or $\mathrm{N}$-limiting conditions) disks, $2.3 \mathrm{~cm}^{2}$ in diameter, were punched from the distal end of the blades. These tissue samples were shipped overnight on ice and then fixed for $4 \mathrm{~h}$ in $2 \%$ glutaraldehyde, $1 \%$ formaldehyde, $2 \% \mathrm{NaCl}, 0.1 \% \mathrm{CaCl}_{2}, 1 \%$ caffeine in $0.1 \mathrm{M} \mathrm{Na}$ cacodylate buffer (pH 7.2) (Clayton \& Ashburner 1994). After rinses in pure 0.1 M Na cacodylate buffer, most specimens were postfixed for $4 \mathrm{~h}$ in $2 \%$ osmium tetroxide, $0.05 \mathrm{M} \mathrm{Na}$ cacodylate buffer. They were rinsed in water, dehydrated in acetone, and then embedded in Spurr's resin. Thin sections for electron microscopy were stained with aqueous $2 \%$ uranyl acetate and Reynold's lead citrate and examined on a Hitachi H-7000 transmission electron microscopy (EM).

The same blocks of embedded samples were used for light microscopy. Sections, 0.5 to $2.0 \mu \mathrm{m}$ thick, were mounted on glass microscope slides and stained with the metachromatic general stain toluidine blue $(1 \%$ toluidine blue in $1 \%$ aqueous sodium borate) or subjected to light microscopic cytochemical procedures. For detection of carbohydrates, sections were stained according to the periodic acid Schiff's (PAS) procedure for unsubstituted carbohydrates (Jensen 1962) and Alcian blue pH 2.5 (Parker \& Diboll 1966) for sulfated and carboxylated carbohydrates. Specific staining of protein was done using aniline blue-black (Fisher 1968) and mercuric bromophenol blue (Mazia et al. 1953) procedures.

\section{RESULTS}

Thalli of Laminaria solidungula grown for $7 \mathrm{mo}$ under either $\mathrm{N}$-replete or N-depleted culture conditions maintained a growth rate of $0.45 \% \mathrm{~d}^{-1}$ (Korb \& Gerard 2000). Thalli in both treatments appeared healthy and were identical in color.

As is typical of kelp anatomy, the surface of the blade of Laminaria solidungula was lined by a thin meristoderm consisting of relatively small, cuboidal cells densely packed with chloroplasts (Figs $1 \& 2$ ). Beneath the meristoderm was a thick cortex that occupied most of the volume of the blade. Cells of the cortex were isodiametric and their size increased with distance from the blade surface, though decreasing somewhat close to the medulla (Fig. 2). Chloroplast abundance in the cortex decreased sharply beneath the meristoderm; most of the cell volume was occupied by vacuole. Mucilage ducts were present in the cortex (Fig. 2). The medulla (Fig. 2), consisting of elongate sieve elements, formed a thin layer in the center of the blade, flanked on either face by the cortex.

Light microscopy of toluidine blue-stained thick sections revealed the presence of diverse structures in the cortex cells. Some types of cell inclusions were present in both N-replete (Fig. 1) and N-depleted (Fig. 2) material $_{i}$ others were found only in the N-replete specimens. The most conspicuous type of inclusion present in both treatments consisted of rounded masses of material (Figs 1 \& 2), often having an intensely stained margin. Toluidine blue staining produced a reddish metachromasia in these inclusions and allowed them to be readily distinguished. They gave a positive reaction for carbohydrates (data not shown) and were neg- 


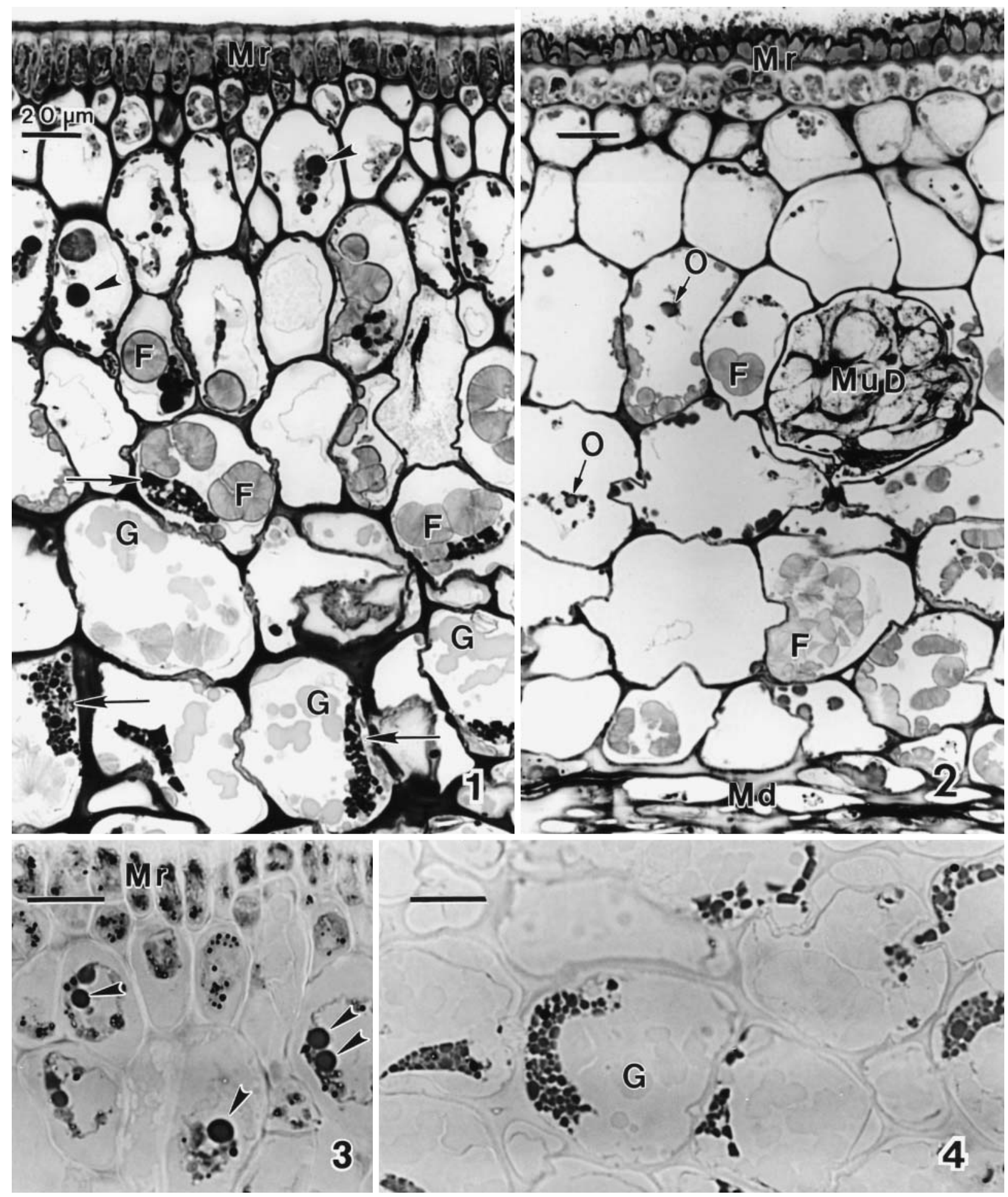

Figs 1 to 4 . Light microscopy, transverse sections of Laminaria solidungula blades; scale bars $=20 \mu \mathrm{m}$. Figs $1 \& 2$. Stained with toluidine blue. Half the thickness of the blade is shown; between the meristoderm (Mr) and central medulla (Md) is a cortex of large, isodiametric cells and mucilage ducts $(\mathrm{MuD})$. Fig. 1. N-replete thallus. Outer cortex cells have spherical inclusions (arrowheads); inner cortex cells contain smaller spherical inclusions (arrows), as well as irregular globular masses (G) that stained less intensely. Osmiophilic bodies (O) and inclusions (F) composed of radiating fibrils (cf. Fig. 11) are also present. Fig. 2. N-depleted thallus. Large hemispherical inclusions $(\mathrm{F})$ and osmiophilic bodies $(\mathrm{O})$ are present but other inclusions common in N-replete thalli are absent. Figs $3 \& 4$. N-replete thalli stained by protein-specific mercuric bromophenol blue procedure. Large spherical bodies (arrowheads) of outer cortex (Fig. 3) and clustered inclusions of inner cortex (Fig. 4) stained intensely, but the irregular globular 
ative for protein. Ultrastructural examination showed these inclusions to consist of radiating fibrils, each fibril being about $15 \mathrm{~nm}$ in diameter (Fig. 11). Because such inclusions were present in both treatments, they will not be considered further here. Osmiophilic bodies, presumed to be physodes, were also present in both treatments and were easily distinguished by their dark green to black color. Many of these bodies appeared unevenly dense (Fig. 10), but this appearance is a common fixation artifact of physodes and lipid bodies (Clayton \& Beakes 1983). The osmiophilic bodies were the second most abundant type of cellular inclusion in the N-depeleted treatment (Fig. 2).

Other types of cell structures were abundant in the $\mathrm{N}$-replete blades (Fig. 1) but were absent from the Ndeficient blades (Fig. 2). Three types of inclusions could be distinguished by unique combinations of anatomical location, size, shape, presence of a bounding membrane, and reactivity to protein stains. All 3 types had a purple-blue (orthochromatic) color after toluidine blue staining. Spherical bodies, up to $10 \mu \mathrm{m}$ in diameter, occurred in the outer cortex (Figs 1 \& 3), whereas more numerous but smaller bodies, sometimes having angular outlines, were common closer to the center of the blade (Figs 1 \& 4). These smaller structures were generally about $2 \mu \mathrm{m}$ across and occurred in large clusters. However, the inclusions in both inner and outer cortex had identical reactions; they were stained by 2 protein-specific protocols, mercuric bromophenol (Figs $3 \& 4$ ) and aniline blue black, but not by the carbohydrate-specific PAS reaction (data not shown). Large and small spherical bodies were sometimes found in the same cells; intermediatesize structures were not common but were found. Each inclusion was located in the cytoplasm and was surrounded by a single membrane (Figs 5, 6 \& 7), and the matrices of all these inclusions were similarly granular. Based on these observations, we view the various membrane-bounded proteinaceous inclusions as a single class of developmentally connected cell structures. Presumably, the proliferation and close packing of the inclusions caused the ordinarily spherical bodies to develop angular outlines (Fig. 5). Collectively, the various protein bodies appeared to occupy more cell volume than all typical organelles combined, and the protein-specific staining results indicated that these inclusions represented most of the protein present within the cortex cells.

Within the clusters of angular to spherical inclusions, irregularly shaped structures sometimes were present (Fig. 6). Also membrane-bounded, the contents of these structures were indistinguishable from those of the larger inclusions. Some spheres were found to have membranous appendages filled with granular material (Fig. 6). Whether these irregularly shaped ele- ments represented a stage of deposition or mobilization of the proteinaceous material is unknown, but they sometimes showed intimate spatial association with chloroplasts (Figs 6 \& 7), with the bounding membrane of the inclusion being fully appressed to the chloroplast envelope. Ribosomes were not present on the bounding membranes of the protein bodies (Figs 5, 6 \& 7).

A third morphological type of inclusion was present in cortex cells of the N-replete specimens and absent from the $\mathrm{N}$-depleted specimens. These inclusions formed irregular globular masses whose shapes suggested fusion of spherical units (Fig. 1). When stained by toluidine blue, they were the same blue color as the spherical protein bodies, but the color was much less intense. At the ultrastructural level the globular masses had a diffuse, ill-defined surface and no bounding membranes (Fig. 8). Little staining of these inclusions was produced by any of the specific stains, but some images suggested that they were developmentally connected to the clustered protein bodies (Fig. 8). Loss of a bounding membrane may have allowed reduced compaction of spherical protein bodies, thus accounting for both the fusion and weak staining of the irregular masses.

Membranous ghosts and empty cytoplasmic compartments (Figs 9 \& 10) were present in thalli subjected to $\mathrm{N}$-depleted conditions. The anatomical distribution of these unusual structures was similar to that of the protein bodies in the N-replete treatment, which suggests that the empty compartments were the remains of mobilized protein bodies. No intact, membrane-bounded protein inclusions were observed in these specimens, nor were fused globular masses present. Plastids were less abundant in the $\mathrm{N}$-depleted specimens and many of the plastids appeared to be degenerating, with much of their volume occupied by amorphous electron-dense material.

\section{DISCUSSION}

Starch and lipids provide compact, osmotically inactive carbon reserves; our study shows that protein inclusions may provide compact, osmotically inactive nitrogen reserves. It is well documented that kelps from seasonally low $\mathrm{N}$ environments may store organic or inorganic forms of $\mathrm{N}$ and that these storage pools can be drawn upon by the alga when ambient nutrients are insufficient to sustain growth (e.g. Chapman \& Craigie 1977, Korb \& Gerard 2000). Pools of inorganic ions, amino acids, soluble proteins, and photosynthetic pigments are easily monitored. However, in the case of proteins, chemical determination of total protein does not readily distinguish protein that is essential for 
immediate physiological function from that which is present in oversupply and might serve in $\mathrm{N}$ storage. In contrast, microscopy readily demonstrates cellular structures that might be potential stores of $\mathrm{N}$ and whose presence can be correlated with environmental conditions. Our study documents the presence of
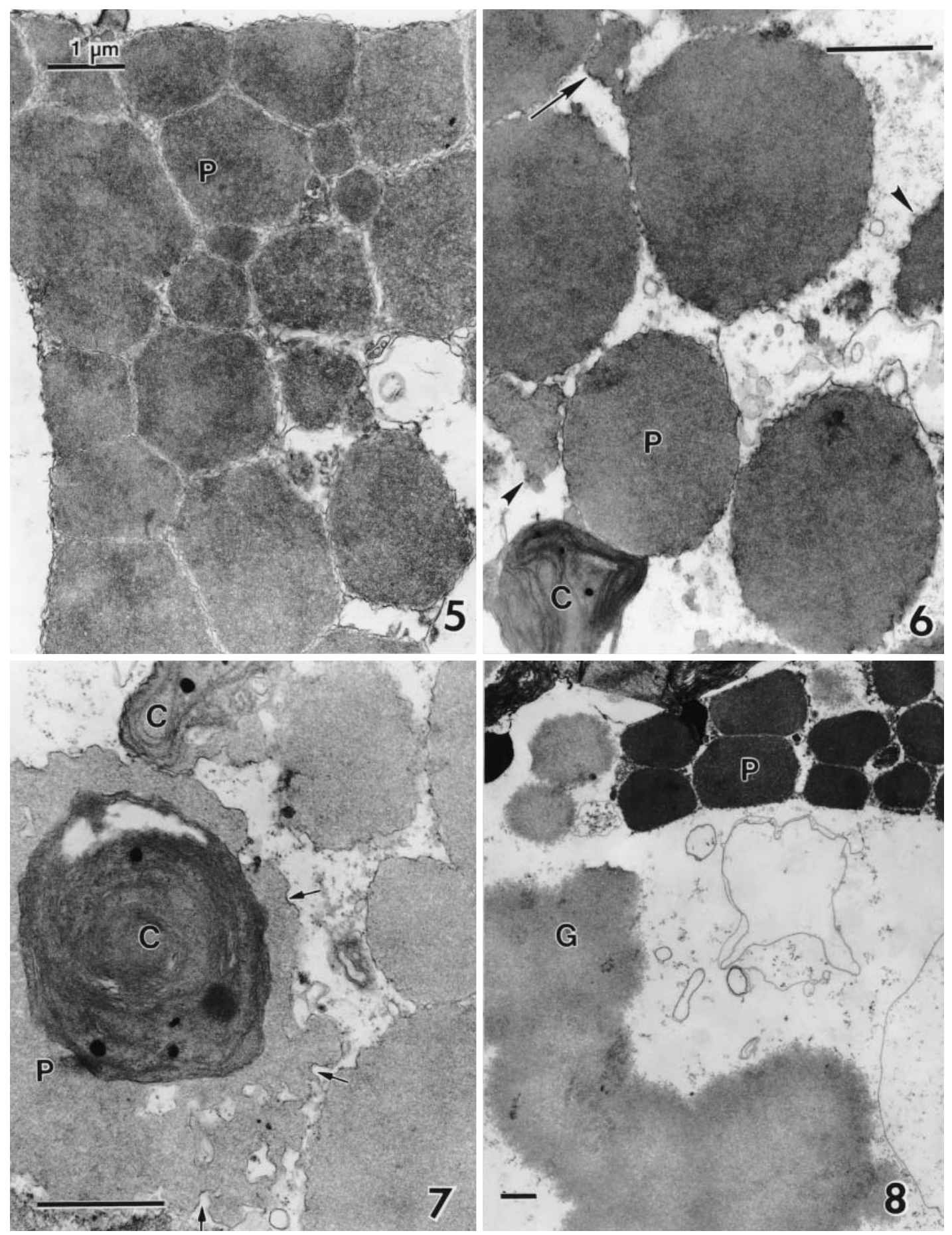

Figs 5 to 8. Transmission EM of N-replete Laminaria solidungula; scale bars $=1 \mu \mathrm{m}$. Fig. 5 . Membrane-bounded protein bodies (P) are numerous and tightly clustered. Fig. 6. Irregularly shaped, membrane-bounded structures (arrowheads) may be appendages (arrow) to spherical protein bodies. Chloroplast (C) shows spatial association with a protein body. Fig. 7. Chloroplasts (C) are closely associated with protein bodies; one chloroplast appears in section to be surrounded by a protein body with a convoluted outline (arrows). Fig. 8. Membrane-bounded protein bodies (P) are adjacent to globular masses of diffuse material without bounding membranes $(\mathrm{G})$ 

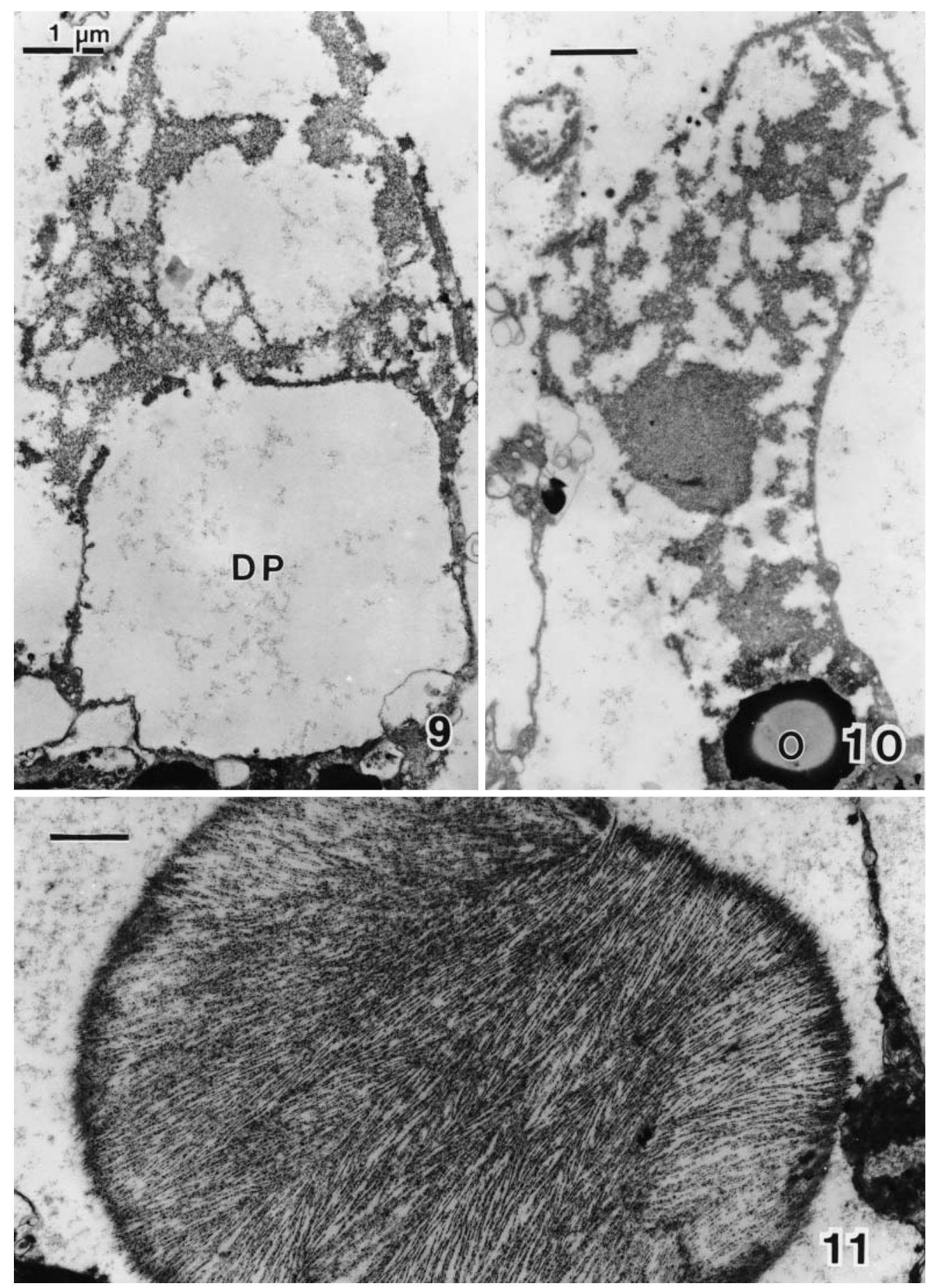

Figs 9 to 11. Transmission EM of Laminaria solidungula; scale bars $=1 \mu \mathrm{m}$. Figs $9 \& 10$. N-depleted thallus. Protein bodies are absent; empty chambers in the parietal cytoplasm of cortex cells may be remnants of protein bodies depleted of contents (DP). Osmiophilic bodies (O) are present. Fig. 11. Hemispherical cellular inclusions in both N-replete and N-depleted thalli are composed of slender, radiating fibrils

abundant microscopically detectable proteinaceous cellular inclusions in thalli grown under a high ambient $\mathrm{N}$ regime and the absence of such inclusions in thalli grown under conditions of $\mathrm{N}$ deficiency. These findings support the proposal of Pueschel (1990, 1992, 1994) that some protein bodies in marine macroalgae provide an additional mechanism by which $\mathrm{N}$ is stored as a buffer against seasonal $\mathrm{N}$ deficiency. 
Although the cells of Laminaria solidungula contained a surprising array of unusual inclusions, cytochemical and ultrastructural findings suggest that all structures uniquely present in N-replete cells were ontogenetically related. Irregularly shaped inclusions had contents that were visibly indistinguishable from those of the variously sized spherical inclusions; furthermore, some spherical and non-spherical inclusions were found to be physically continuous. The masses of diffuse material that stained weakly may have resulted from fusion of spherical inclusions that lost their bounding membranes (possibly artifactually). These interpretations could be tested by identification of the protein and immunolabeling of the various inclusions to determine whether their contents are chemically identical.

The intimate spatial association of chloroplasts with irregularly shaped protein bodies raises the possibility of a role of chloroplasts in the synthesis of these proteins. Identification of the particular proteins sequestered in these bodies will aid in understanding the basis of this striking spatial association.

Protein inclusions are widespread in the red algae, having been demonstrated in at least 12 orders (e.g. Giraud \& Cabioch 1983, Wetherbee et al 1984, Ekman et al 1989, Pueschel 1992). Most red algal protein bodies that have been described were crystalline, i.e., having angular outlines or periodic substructure or both. By contrast, there are few reports of protein inclusions in vegetative cells of brown algae; however, this situation may reflect differing intensity of ultrastructural study of red and brown algae rather than a difference in the biology of the 2 groups. Among the reports of crystals in brown algae is a description of crystals in Laminaria hyperborea (as L. cloustoni) by Chadefaud (1936), but the chemical composition of the crystals was not elucidated. More recently, Haplogloia kuckuckii (Chordariales) was shown to have membranebounded protein crystals in axial filaments (Pueschel 1994).

In the absence of crystallinity, distinguishing membrane-bounded protein storage bodies from secretory vesicles or other transient structures is more difficult. Nevertheless, the abundance, large size, and location in metabolically less active cortex cells in N-replete thalli, and the presence of only depleted inclusions in $\mathrm{N}$-deficient cultures leave little doubt that non-crystalline protein bodies in Laminaria solidungula function in storage rather than secretion.

It remains to be determined exactly when the protein inclusions are utilized in relation to other $\mathrm{N}$ pools in Laminaria solidungula. Korb \& Gerard (2000) demonstrated that $\mathrm{N}$-replete plants contained large pools of $\mathrm{NO}_{3}{ }^{-}$at approximately $50 \mu \mathrm{mol} \mathrm{g}{ }^{-1}$ fresh wt. With growth rates of $0.45 \% \mathrm{~d}^{-1}$ at $0^{\circ} \mathrm{C}$, these nitrate pools alone could support growth for approximately $35 \mathrm{~d}$. Indeed, after just $1 \mathrm{mo}$ of $\mathrm{N}$-limiting conditions, internal $\mathrm{NO}_{3}{ }^{-}$concentrations had declined to extremely low values (less than $5 \mu \mathrm{mol} \mathrm{g}^{-1}$ fresh $\mathrm{wt}$ ); however, labile organic $\mathrm{N}$-compounds, including free amino acids, soluble protein and chlorophyll $a$, were not utilized to support growth until after 3 mo of $\mathrm{N}$ limitation. The presence of protein bodies was not examined until after $28 \mathrm{wk}$ of $\mathrm{N}$ limitation. If such protein does indeed represent a 'stored' portion of total thallus protein, then this may have provided the unexplained $\mathrm{N}$ source that supported the growth of L. solidungula in the laboratory when tissue $\mathrm{NO}_{3}{ }^{-}$levels were low or depleted. In the Arctic, $\mathrm{N}$ limitation rarely lasts longer than 3 mo (Chapman \& Lindley 1980, Dunton 1985) and if sufficient $\mathrm{N}$ reserves have been accumulated, macroalgal growth and maintenance costs could be supported during this period.

Protein may be viewed as an energetically unfavorable $\mathrm{N}$ source, especially in high latitude algae receiving low annual inputs of irradiance. Prior to incorporation into organic compounds, all $\mathrm{N}$ sources must first be reduced to $\mathrm{NH}_{4}{ }^{+}$(Syrett 1981). High rates of carbon fixation have been reported in Laminaria solidungula and are a function of exposure to saturating levels of PAR (Dunton 1990). Elevated photosynthetic performance has been observed both in the field during the summer months (Dunton \& Jodwalis 1988) and under laboratory conditions in which light levels were saturating for growth (Korb \& Gerard 2000), and could potentially provide the reducing power necessary to utilize protein stores. Arctic kelps rely heavily on carbon stores accumulated during the summer to support growth during the light limited winter months (Dunton \& Schell 1986, Dunton \& Jodwalis 1988, Dunton 1990). The summer months are also characterized by low ambient $\mathrm{NO}_{3}{ }^{-}$(Chapman \& Craigie 1977, Dunton 1985). Therefore, carbon fixation rates need to be maximized over the period of increased irradiance despite the constraints of a low $\mathrm{N}$ supply. The inclusions found in N-replete L. solidungula may provide an osmotically inactive nitrogen supply that can be utilized during periods of high carbon fixation; thus, ensuring that organic nitrogenous components of the photosynthetic apparatus work efficiently despite the constraints of $\mathrm{N}$ limitation during the brief Arctic summer.

Acknowledgements. We thank Dr Ken Dunton for supplying Laminaria solidungula and Rick Chow, Henry Eichelberger, and John Reese for technical assistance. This work was supported in part by National Science Foundation Grant OPP 9521496 to Dr Valrie Gerard, and her support and encouragement are gratefully acknowledged. 


\section{LITERATURE CITED}

Bird KT, Habig C, DeBusk T (1982) Nitrogen allocation and storage patterns in Gracilaria tikvahiae (Rhodophyta). J Phycol 18:344-348

Chadefaud M (1936) Le cytoplasme des Algues vertes et des Algues brunes, ses éléments figurés et ses inclusions. Rev Algol 8:1-286

Chapman ARO, Craigie JS (1977) Seasonal growth in Laminaria longicruris: relations with dissolved inorganic nutrients and internal reserves of nitrogen. Mar Biol 40: 197-205

Chapman ARO, Lindley JE (1980) Seasonal growth of Laminaria solidungula in the Canadian High Arctic in relation to irradiance and dissolved nutrient concentrations. Mar Biol 57:1-5

Clayton MN, Ashburner CM (1994) Secretion of phenolic bodies following fertilisation in Durvillaea potatorum (Durvillaeales, Phaeophyta). Eur J Phycol 29:1-9

Clayton MN, Beakes GW (1983) Effects of fixatives on the ultrastructure of physodes in vegetative cells of Scytosiphon lomentaria (Scytosiphonaceae, Phaeophyta). J Phycol 19:4-16

Dunton KH (1985) Growth of dark-exposed Laminaria saccharina (L.) Lamour. and Laminaria solidungula J. Ag. (Laminariales: Phaeophyta) in the Alaskan Beaufort Sea. J Exp Mar Biol Ecol 94:181-189

Dunton KH (1990) Growth and production in Laminaria solidungula: relation to continuous underwater light levels in the Alaskan High Arctic. Mar Biol 106:297-304

Dunton KH, Jodwalis CM (1988) Photosynthetic performance of Laminaria solidungula measured in situ in the Alaskan High Arctic. Mar Biol 98:277-285

Dunton KH, Schell DM (1986) Seasonal carbon budget and growth of Laminaria solidungula in the Alaskan High Arctic. Mar Ecol Prog Ser 31:57-66

Ekman P, Lignell A, Pedersén M (1989) Localization of ribulose-1, 5-bisphosphate carboxylase/oxygenase in Gracilaria secudata (Rhodophyta) and its role as a nitrogen storage pool. Bot Mar 32:527-534

Fisher DB (1968) Protein staining of ribboned epon sections for light microscopy. Histochemie 16:92-96

Gagné JA, Mann KH, Chapman ARO (1982) Seasonal patterns of growth and storage in Laminaria longicruris in relation to differing patterns of availability of nitrogen in the water. Mar Biol 69:91-101

Gerard VA (1997) The role of nitrogen nutrition in high-

Editorial responsibility: Otto Kinne (Editor),

Oldendorf/Luhe, Germany temperature tolerance of the kelp, Laminaria saccharina (Chromophyta). J Phycol 33:800-810

Giraud G, Cabioch J (1983) Inclusions cytoplasmiques remarquables chez les Corallinacées (Rhodophytes, Cryptonemiales). Ann Sci Nat Bot Biol Veg 5:29-43

Hanisak MD (1983) The nitrogen relationships of marine macroalgae. In: Carpenter EJ, Capone DG (eds) Nitrogen in the marine environment. Academic Press, New York, p 699-730

Henley WJ, Dunton KH (1995) A seasonal comparison of carbon, nitrogen, and pigment content in Laminaria solidungula and L. saccharina (Phaeophyta) in the Alaskan Arctic. J Phycol 31:325-331

Jensen WA (1962) Botanical histochemistry. WH Freeman \& Company, San Francisco

Korb RE, Gerard VA (2000) Effects of concurrent low temperature and low nitrogen supply on polar and temperate seaweeds. Mar Ecol Prog Ser 198:73-82

Levy I, Gantt E (1990) Development of photosynthetic activity in Porphyridium purpureum (Rhodophyta) following nitrogen starvation. J Phycol 26:62-68

Mazia D, Brewer PA, Alfert M (1953) The cytochemical staining and measurement of protein with mercuric bromophenol blue. Biol Bull 104:57-67

Naldi M, Wheeler PA (1999) Changes in nitrogen pools in Ulva fenestrata (Chlorophyta) and Gracilaria pacifica (Rhodophyta) under nitrate and ammonium enrichment. J Phycol 35:70-77

Parker BC, Diboll AG (1966) Alcian stains for histochemical localization of acid and sulfated polysaccharides in algae. Phycologia 6:37-46

Pueschel CM (1990) Cell structure. In: Cole KM, Sheath RG (eds) Biology of the red algae. Cambridge University Press, Cambridge, p 7-41

Pueschel CM (1992) An ultrastructural survey of the diversity of crystalline, proteinaceous inclusions in red algal cells. Phycologia 31:489-499

Pueschel CM (1994) Protein crystals in Haplogloia kuckuckii (Chordariales, Phaeophyceae): another mechanism for nitrogen storage in brown algae? Phycologia 33:91-96

Syrett PJ (1981) Nitrogen metabolism in microalgae. In: Platt $\mathrm{T}$ (ed) Physiological bases of phytoplankton ecology. Can Bull Fish Aquat Sci 210:182-210

Wetherbee R, Janda DM, Bretherton GA (1984) The structure, composition, and distribution of proteinaceous crystalloids in vegetative cells of the red alga Wrangelia plumosa. Protoplasma 119:135-140

Submitted: March 12, 2001; Accepted: May 25, 2001

Proofs received from author(s): July 20, 2001 